\title{
PERKEMBANGAN MANAJEMEN STRATEGI
}

\author{
Son Wandrial ${ }^{1}$
}

\begin{abstract}
Strategic management is an inter-discipline field which develops rapidly these days.Its development follows the other study disciplines like marketing, micro, macro, organization behaviour, etc. Strategic management development is also follows the changes in business environment, like industrial competition, consumer behaviour, and technology. Companies must adapt those changes if they still want to survive in business. If not, they will be lost. In order to survive, experts had announced many concept. And this article will briefly explain about the main concept which contributes in strategic management development.
\end{abstract}

Keyword: strategic management

ABSTRAK
Manajemen Strategi adalah suatu bidang ilmu yang interdisiplin dan berkembang
dengan pesat pada beberapa waktu belakangan ini. Ilmu itu berkembang seiring dengan
perkembangan disiplin ilmu lain, seperti pemasaran, mikro, makro, perilaku organisasi, dan
banyak lagi. Perkembangan ilmu itu juga sejalan dengan perubahan yang terjadi pada
lingkungan, seperti persaingan di industri, perilaku konsumen, dan teknologi. Perusahaan harus
dapat mengadaptasi perubahan tersebut bila ingin tetap bertahan dalam bisnisnya. Jika tidak
maka akan terlindas oleh perubahan tersebut. Untuk tetap dapat bertahan, banyak konsep yang
diperkenalkan oleh para pakar. Artikel ini menerangkan secara singkat konsep utama yang
menjadi penyumbang dalam perkembangan ilmu manajemen strategi tersebut.
Kata kunci: manajemen strategi

${ }^{1}$ Staf Pengajar Fakultas Ekonomi, UBiNus, Jakarta 


\section{PENDAHULUAN}

Dalam abad globalisasi yang didukung oleh revolusi informasi dan diperkuat oleh kemajuan teknologi, perbatasan nation states akan runtuh. Demikian pendapat dan penulis Jepang yang mempunyai reputasi internasional, Kenichi Ohmae dan bukunya The End of The Nation State. Pengaruh siaran TV, seperti CNN yang dapat ditangkap dimana-mana oleh antena parabola, menyebabkan nation state tidak lagi dapat menyensor warga negaranya mengetahui apa yang terjadi di dunia, bahkan di negaranya sendiri. Beberapa tahun terakhir biaya telepon internasional tidak akan melebihi tarif domestik. Semua orang dapat menggunakan e-mail secara murah. Di lain pihak, negara berkembang pun ramai-ramai ikut mode untuk menggabungkan diri pada berbagai rencana kawasan perdagangan bebas, seperti AFTA dan APEC. Pada kumpulan ekononomi regional, sama sekali tidak dibayangkan bahwa kedaulatan negara akan dikorbankan atau ditelan oleh suatu wewenang supranasional.

Akan tetapi, di Eropa ada gejala, baik ekonomi maupun politik, negara yang bergabung dengan Uni Eropa berangsur-angsur menyerahkan berbagai wewenang kepada Brussel yang merupakan pusat pemerintahan dari Uni Eropa. Gejala borderless world akan meluas dalam jaman informasi elektronika dan GATT/WTO pascaputaran Uruguay. Hal tersebut tentunya membawa implikasi terhadap dunia bisnis. John Naisbitt menyebut era saat ini sebagai "the most exiting decade". Bagaimana perusahaan berperilaku dan menerapkan strategi bersaing untuk memenangkan persaingan di era globalisasi mendorong penulis untuk membahas mengenai perkembangan manajemen strategi.

Penulis memulai pembahasan pada evolusi dari manajemen strategi dilanjutkan dengan konsep keunggulan bersaing yang diperkenalkan Michael Porter dan bukunya Competitive Strategy. Pada awal tahun 1990-an, C.K Prahalad dan Garry Hamel memperkenalkan konsep komptensi inti sebagai faktor penentu bagaimana perusahaan dapat memenangkan persaingannya. Setelah itu, secara berturut-turut penulis membahas Hypercompetition dari Richard D'Aveni dan Crafting Strategy dari Henry Mintzberg.

\section{PEMBAHASAN}

\section{Evolusi Strategic Planning}

\section{Budgeting and Financial Control}

1. Merupakan perwujudan awal managerial system.

2. Merupakan suatu prosedur formal untuk menetapkan proses administrasi yang digunakan oleh para manajer dalam menjalankan perusahaan.

3. Budgets merupakan proyeksi dari revenue dan costs dalam jangka waktu tertentu, biasanya satu tahun.

4. Master budget dipakai untuk memonitor perkembangan bisnis perusahaan, diantaranya sales, manufacturing, administrative activities, investment, dan cash management. 
5. Financial Control adalah suatu sistem administrasi sebagai responss terhadap kebutuhan pada manajemen kas yang lebih baik, efisiensi dalam operasional, penurunan biaya, dan keterbatasan sumber daya keuangan.

6. Penggunaan rasio keuangan sebagai suatu alat ukur, antara lain sebagai berikut.
a. Liquidity Ratios
b. Leverage Ratios
c. Profitability Ratios
d. Turnover Ratios
e. Common Stock Security Ratios

\section{Long-Range Planning}

1. Organisasi sudah mulai untuk mendefinisikan objectives, goals, program, dan budget untuk periode beberapa tahun (biasanya lima tahun).

2. Muncul sebagai respons dari pertumbuhan pasar yang belum pernah terjadi sebelumnya, tidak cukup lagi kalau hanya berpegangan pada proyeksi budget yang cuma satu tahun saja.

2. Starting point adalah pada multi year forecast dari penjualan perusahaan.

3. Forecasting berdasarkan pada proyeksi historis, biasanya lima tahun.

4. Dalam long-range planning, pertama kali diperkenalkan penggunaan teknik pay-back dan discounted cash flow.

5. Long-range planning, dapat dijalankan dengan kondisi sebagai berikut.
a. Pertumbuhan pasar yang tinggi.
b. Tren yang dapat diprediksi.
c. Perusahaan memiliki satu bisnis tunggal.
d. Tingkat persaingan yang relatif rendah.

6. Jika salah satu dari kondisi tersebut tidak dapat terpenuhi maka long-range planning akan sulit untuk dijalankan.

7. Long-range planning tidak dapat bekerja bila terdapat perubahan lingkungan eksternal dan tingkat persaingan yang tinggi

\section{Business Strategic Planning}

1. Tahun 60-an terjadi perubahan lingkungan yang penting di Amerika Serikat, yaitu pertumbuhan yang terus menurun dan meningkatnya tingkat persaingan di beberapa industri kunci Amerika.

2. Bergesernya fokus perhatian manajerial dari produksi ke marketing.

3. Terdapat peningkatan pada diversifikasi yang dilakukan beberapa perusahaan penting melalui proses akuisisi yang agresif.

4. Munculnya konsep Segmentasi Bisnis, membagi-bagi bisnis dalam suatu unit atau entitas tertentu yang independen dan autonomous, entitas tersebut yang sekarang dikenal dengan Strategic Business Unit (SBU).

5. Dengan munculnya SBU itu, memungkinkan manajer secara bebas mengontrol bisnis yang dibawahinya, bebas menentukan strategi yang tepat, memiliki konsumen tertentu, menghadapi pesaing tertentu, tidak harus tergantung dengan bisnis (SBU) lainnya

6. Munculnya Business Portfolio Approach, model yang digunakan seperti diketahui sekarang ini, yaitu Boston Consulting Group Approach (BCG) dan General Electric (GE) Approach.

7. Mulai diperkenalkan dan digunakannya konsep analisis persaingan model dari Porter. 
a. Five forces Porter Industry Analysis: Competing among firms rivalry, bargaining power of buyer, bargaining power of supplier, new entrants, substitute product.

b. Porter's Generic Strategy:

- overall cost leadership

- differentiation

- focus

8. Beberapa elemen dasar dalam Business Strategic Planning sebagai berikut.

a. Misi dari bisnis

b. Analisis lingkungan: eksternal dan internal

c. Formulasi strategi bisnis

d. Mendefinisikan dan evaluasi program.

e. Alokasi sumber daya.

f. Budgeting, program pendanaan strategis

9. Formal Business Strategic Planning process as follows.

a. The Mission of the Business

b. Formulation of business strategy and broad action program

c. Formulation and evaluation of specific actions program

d. Resources allocation and definition of performance measurements for management control

e. Budgeting at business level

f. Budgeting considerations and approval of strategic and operational funds

7. Business strategic planning juga merupakan suatu proses pembelajaran dan terjadi sharing dalam hal corporate value, corporate phylosophy, pemahaman yang mendalam akan kumpulan bisnis dari perusahaan, serta kompetensi manajerial dan profesionalisme

\section{Corporate Strategic Planning}

1. Perkembangan di bidang elektronik membawa dampak perubahan yang pesat di sisi teknologi.

2. Bisnis dari perusahaan berhadapan dengan pesaing baru, yaitu Jepang yang menjadi pesaing terkuat bagi mereka. Hal itu membuat peta persaingan menjadi semakin ketat dan sengit.

3. Proyeksi pada pasar internasional dikarenakan adanya uncertainty (ketidakpastian). Penyebabnya adalah inflasi, foreign exchange rate, dan kondisi perekonomian negara yang berbeda-beda di seluruh dunia

4. Ketidakpastian muncul juga disebabkan oleh perilaku yang lebih tegas dari kelompok tertentu dalam masyarakat yang menuntut perhatian yang lebih besar dari perusahaan terhadap lingkungan sekitarnya. Kelompok tersebut adalah stakeholders. Stakehoders bukan hanya terdiri dari pemegang saham, creditor, klien, supplier, manager, dan karyawan saja tetapi juga pemerintah, masyarakat, konsumen, aktivis lingkungan hidup, dan lain sebagainya.

5. Tekanan lingkungan eksternal memaksa perusahaan untuk mempertimbangkan kembali kebijakan alokasi atau sharing sumber daya (fasilitas manufakturing, jaringan distribusi, tenaga penjualan, dan lainnya) yang dimiliki kepada masing-masing SBU. Pertimbangannya pada pengurangan biaya dan peningkatan efisiensi untuk mengalahkan pesaing. 


\section{Perubahan Pandangan terhadap Segmentasi Bisnis}

1. Muncul dilema bagaimana caranya agar ada kesesuaian dan konsistensi antara fokus strategi untuk segmen pasar yang berbeda dengan struktur organisasi fungsional. Untuk itu, harus dibentuk suatu kelompok dalam struktur organisasi yang dapat menjembatani antara struktur dan strategi.

2. Interrelationship antara satu SBU dengan SBU lainnya, yaitu shared resources dan shared concerns. Digunakannya konsep value-added chain untuk mengidentifikasi shared resources dan shared concerns.

3. Dalam proses corporate strategic planning terdapat tiga level hierarki dari planning sebagai berikut.

1. Corporate level

2. Business level

3. Functional level

4. Corporate Strategic Planning Process

a. The Vision of the firm: corporate philosophy, mission of the firm and identification of SBUs and their interactions.

b. Strategic posture and planning guidelines: corporate strategic thrust, corporate performance objectives and planning challenge.

c. The mission of the business: business scope and identification of products market segments.

d. Formulation of business strategy and broad action programs.

e. Formulation of functional strategy.

f. Consolidation of business and functional strategies.

g. Definition and evaluation of specific action program at the business level.

h. Definition and evaluation of specific action program at the functional level.

i. Resources allocation and definition of performance measurements for management control.

j. Budgeting at business level.

k. Budgeting at functional level.

l. Budgeting consolidations and approval of strategic and operational funds.

\section{Strategic Management}

1. Strategic planning tidak akan berguna bila tidak ada dukungan, masukan, dan komitmen dari lower level manager.

2. Planning harus terintegrasi dengan sistem administrasi yang ada di perusahaan, seperti management control, komunikasi dan informasi, serta motivasi dan rewards.

3. Sistem adminstrasi dan struktur organisasi harus dapat dikoordinasikan dengan baik dengan culture (budaya) dari perusahaan. 


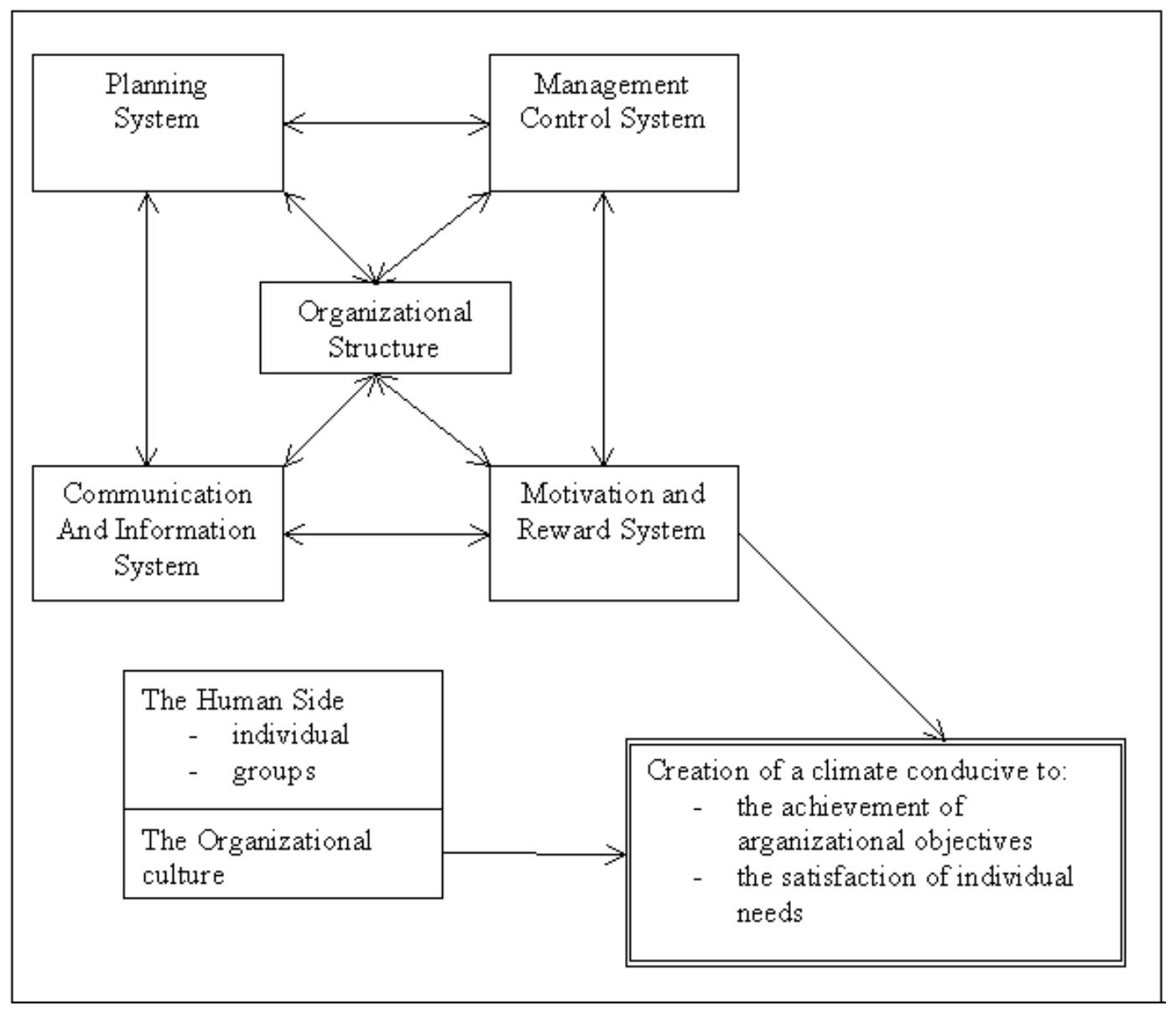

Gambar 1 Model Strategic Management

\section{Keunggulan Bersaing dari Michael Porter}

Persaingan dalam industri disajikan oleh tulisan yang sangat terkenal pada tahun 1980-an oleh Michael Porter, dalam bukunya Competive Strategy. Dalam tulisan tersebut, diperkenalkan suatu analisis persaingan industri yang akan menentukan keberhasilan perusahaan dalam memenangkan persaingan, yaitu dengan menganalisis industri perusahaan yang terdiri dan lima kekuatan utama yang saling tarik menarik sehingga menentukan intensitas dan karakteristik persaingan. 


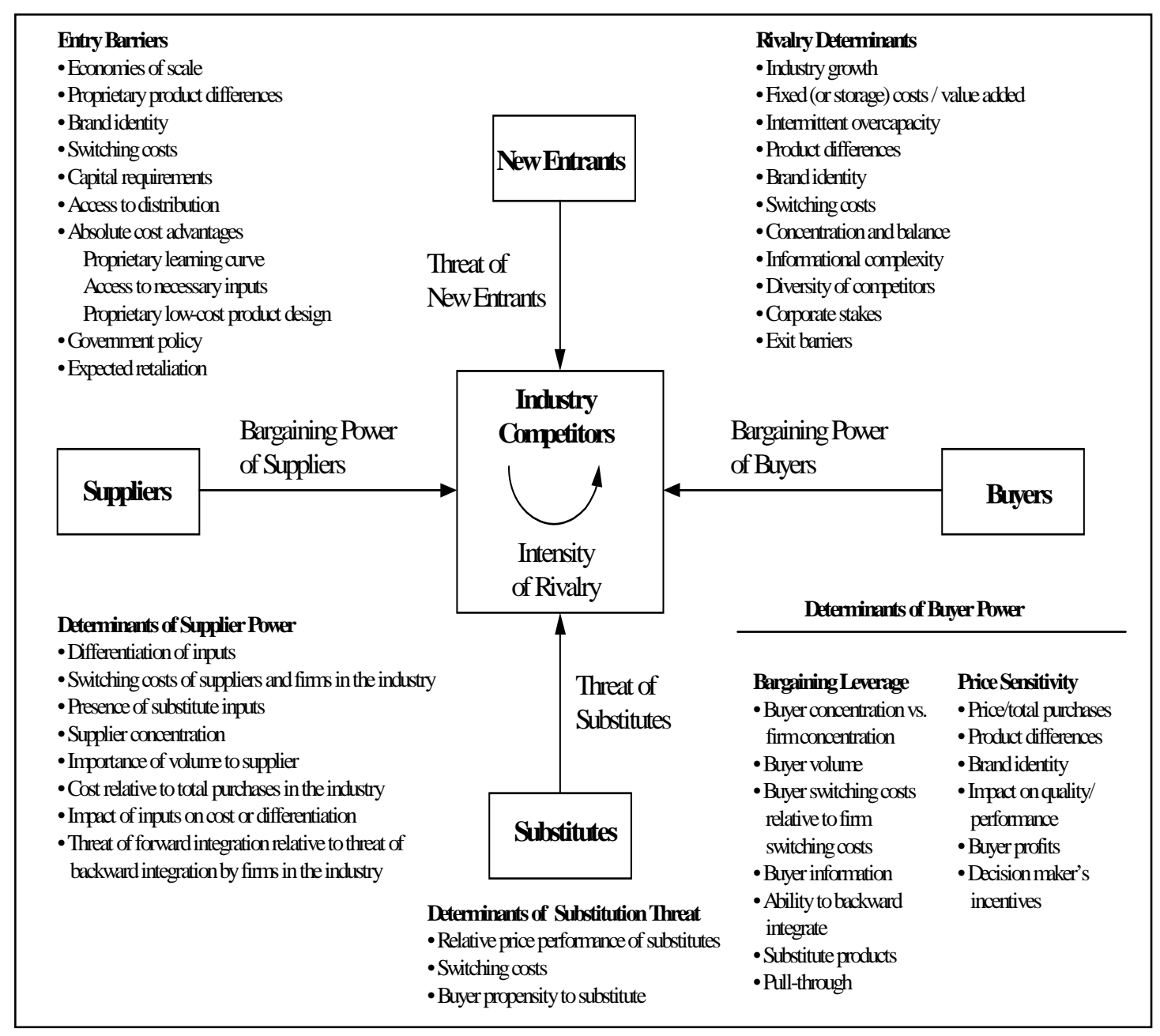

Gambar 2 Porter Five Forces

\section{Ancaman Masuknya Pendatang Baru}

Pendatang baru yang masuk ke dalam industri dapat menyebabkan intensitas persaingan meningkat. Besar kecilnya ancaman tersebut ditentukan oleh ada tidaknya hambatan bagi pendatang baru untuk memasuki industri. Besar kecilnya hambatan masuk, antara lain ditentukan oleh hal berikut.
a. Skala ekonomi
b. Diferensiasi produk
c. Capital requirement
d. Switching cost
e. Akses ke saluran distribusi
f. Kebijakan pemerintah 


\section{Tingkat Rivalitas di Antara Pesaing yang Ada}

Tingkat rivalitas di antara pesaing merupakan upaya masing-masing pesaing memenangkan persaingan melalui penerapan strategi harga, promosi, peningkatan kualitas pelayanan, dan lain-lain. Intensitas persaingan antarperusahaan ditentukan oleh beberapa factor, seperti berikut ini.
a. Adanya beberapa pesaing yang seimbang.
b. Perumbuhan industri yang lambat.
c. Kurangnya diferensiasi atau switching cost.
d. Pertambahan kapasitas yang tinggi.
e. Hambatan pengunduran diri yang tinggi.

\section{Tekanan dari Produk Pengganti}

Produk pengganti adalah suatu produk yang fungsinya dapat menggantikan fungsi produk suatu industri. Besar kecilnya ancaman produk pengganti tergantung dari tingkat harga dan kualitas produk pengganti dibandingkan dengan produk suatu industri.

\section{Kekuatan Tawar Menawar Pembeli}

Kekuatan tawar menawar pembeli akan besar jika terjadi hal berikut.

a. Pembeli membeli dalam jumlah besar.

b. Produk yang dibeli adalah produk standar dan tidak terdiferensiasi.

c. Pembeli memperoleh benefit yang rendah.

d. Produk industri bukan merupakan produk yang terlalu dibutuhkan oleh pembeli, seperti barang mewah.

e. Pembeli menempatkan suatu ancaman melakukan backward integration untuk membuat produk industri.

\section{Kekuatan Tawar Menawar Pemasok}

Kekuatan tawar menawar pemasok ditentukan oleh hal berikut.

a. Industri pemasok didominasi oleh sedikit perusahaan.

b. Produk pemasok merupakn produk unik.

c. Industri tersebut bukan merupakan pelanggan penting bagi pemasok.

d. Pemasok meperlihatkan ancaman untuk melakukan forward integration.

Michael Porter juga memperkenalkan strategi yang dapat diterapkan oleh perusahaan dalam upayanya memenangkan persaingan. Porter menyebutnya sebagai generic strategy yang terdiri atas hal berikut.

\section{Cost Leadership Strategy}

Cost Leadership Strategy adalah suatu strategi untuk memenangkan persaingan melalui efisiensi biaya produksi sehingga perusahaan memiliki total biaya rendah dan dapat menerapkan 
strategi harga dengan tingkat harga rendah dibandingkan dengan pesaing. Misalnya, strategi cost leadership yang diterapkan Wal Mart dan efisiensi biaya produksi yang dilakukan membuat Wal Mart dapat menerapkan strategi harga yang lebih rendah dibandingkan para pesaingnya.

\section{Differentiation Strategy}

Strategi diferensiasi adalah strategi untuk memenangkan persaingan melalui diferensiasi produk, sehingga produk perusahaan memiliki keunggulan pada diferensiasi yang dipilihnya.

\section{Focus}

Strategi fokus mempunyai dua varian, yaitu fokus biaya dan diferensiasi. Strategi fokus menuntut perusahaan untuk memilik suatu segmen atau kelompok segmen dalam industri dan menyesuaikan strateginya untuk melayani segmen yang dipilih.

\begin{tabular}{|c|c|c|c|}
\hline & & \multicolumn{2}{|c|}{ COMPETITIVE ADVANTAGE } \\
\hline & & Lower Cost & Differentiation \\
\hline & $\begin{array}{l}\text { Broad } \\
\text { Target }\end{array}$ & 1. Cost Leadership & 2. Differentiation \\
\hline & $\begin{array}{l}\text { Narrow } \\
\text { Target }\end{array}$ & 3A. Cost Focus & $\begin{array}{l}\text { 3B. Differentiation } \\
\text { Focus }\end{array}$ \\
\hline
\end{tabular}

Gambar 3 Porter's Generic Strategy

Dalam kerangka formulasi strategi, konsep Porter tersebut biasanya digunakan untuk melakukan analisis industri untuk menentukan besarnya peluang dan ancaman yang dihadapi perusahaan.

\section{Kompetisi Masa Depan (CK Prahalad dan Gary Hamel)}

\section{Kompetensi Inti}

Apa yang dimaksud dengan kompetensi inti? Dalam bukunya yang berjudul Manajemen Strategi: Sebuah Konsep Pengantar, Setiawan HP menganalogikan perusahaan sebagai pohon dan kompetensi inti merupakan akarnya. Kompetensi inti diperkenalkan oleh Hamel dan Prahalad yang 
diartikan sebagai kumpulan keterampilan dan teknolgi yang memungkinkan suatu perusahaan menyediakan manfaat tertentu kepada pelanggan.

Semua kompetensi inti merupakan kapabelitas tetapi sebaliknya, tidak semua kapabelitas merupakan kompetensi inti. Hanya kapabelitas yang memiliki kriteria tertentu yang dapat dimasukkan sebagai kompetensi inti.

1. Valueable Capabilities. Kapabelitas yang memungkinkan perusahaan dapat memanfaatkan peluang dan meminimalkan ancaman yang dihadapi

2. Rare capabilitis. Kapabelitas yang dimiliki oleh sangat sedikit pesaing.

3. Imperfectly Imitable Capabilities. Kapabelitas yang tidak mudah dikembangkan oleh para pesaing

4. Nonsubstitutable Capabilities. Kapabelitas yang tidak dapat disubstitusikan.

Hamel dan Prahalad juga memperkenlakan istilah strategic intent. Apakah Strategic intent itu? strategic intent adalah penyusunan strategi dang didasari oleh visi dan dikembangkan secara bertahap dan konsisten, "It is about rolling the future back into today". Setiawan HP mendefinisikan strategic intent sebagai pemberdayaan sumber daya yang dimiliki perusahaan secara optimal. Strategic intent memiliki tiga komponen berikut.

\section{Stretch}

Stretch adalah menciptakan aspirasi dan ambisi yang mungkin pada mulanya atau dalam kondisi normal, dirasakan tidak mungkin. Hal tersebut akan mendorong perusahaan dan karyawannya untuk merealisasikannya. Jadi, merupakan energi emosional yang menyatukan semua sumber daya yang dimiliki perusahaan untuk mencapai mimpinya.

\section{Foresight}

Agar energi emosional terarah dengan tepat, dibutuhkan foresight yang tidak hanya memprediksi masa depan tetapi juga berimajinasi tentang masa depan seperti apa yang harus diciptakan oleh perusahaan berdasarkan berbagai kecendrungan yang ada, misalnya kecenderungan teknologi, perilaku konsumen, lingkungan, dan sebagainya.

\section{Leverage}

Leverage adalah bagaimana menciptakan pengaruh yang lebih besar dengan sumber daya yang dimiliki oleh perusahaan saat ini.

\section{Kompetisi Menuju Masa Depan}

Hamel dan Prahalad membuka tulisan dalam bukunya Competing for the Future dengan menanyakan berapa porsi waktu perusahaan untuk memikirkan masa depan. Jika perusahaan memiliki porsi yag terbesar untuk memikirkan kondisi perusahaan yang dihadapi saat ini, siapsiaplah untuk tergilas oleh lokomotif persaingan yang terus melaju menuju masa depan. Menurut Hamel dan Prahalad, perusahaan yang memiliki mimpilah yang akan muncul menjadi pemenang. Mimpi, menurut Hamel dan Prahald, merupakan sumber energi yang menggerakkan seluruh otot dan syaraf organisasi. Mimpi disini dimaksudkan sebagai visi. Hamel dan Prahalad menyebut konsepnya sebagai strategic intent. Strategi harus dimulai dengan visi. Misalnya, mimpi 
Motorola terhadap dunia tanpa kabel (wireless). Dalam mimpi itu digambarkan suatu ketika nomor telepon tidak dicantumkan pada pesawat telepon tetapi pada manusia. Jadi, mereka bermimpi bahwa suatu ketika semua manusia akan mengantungi telepon portable.

Karena menyangkut soal visi, strategi harus memiliki pandangan ke depan. Pemenangnya dapat melakukannya dengan berbagai cara. Menciptakan monopoli terhadap produk tertentu ketika pesaing belum berani memulai (Sony melalui walkman dan Chrysler dengan minivans-nya), menciptakan standar sehingga yang lain harus mengikuti standar tersebut (Matshushita dengan VCR-nya dan Microsoft dengan DOS-nya) atau mempelopori rule of game yang baru (seperti discount stores-nya Wal Mart).

Dalam strategic intent, mimpi harus memiliki obsesi untuk menang dan harus dicapai secara bertahap. Canon melakukannya dengan mematok Xerox dengan emosi yang sangat terkendali. Mula-mula mereka memahami teknologi dan hak paten. Xerox kemudian mengambil lisensi Xerox untuk masuk pasar. Hal itu adalah awal untuk mengembangkan R\&D nya sendiri. Teknologi sendiri ditemukan lalu ditawarkan kepada industri lain untuk membiayai kegiatan R\&D lainnya. Setelah siap, baru masuk ke berbagai segmen pasar di Jepang dan Eropa dimana Xerox tidak dominan.

Dalam strategic intent, masa depan bukan hanya harus dibayangkan tetapi harus dibangun. Jadi, dibutuhkan seorang arsitek yang dapat menciptkan hal yang belum tercipta, gabungan antara dreamer dan draftsman, antara seni dengan rekayasa. Dalam kegiatan itu, muncul istilah strategic architecture yang merupakan gabungan antara information architecture (pengetahuan tentang masa depan), social architecture (perilaku, nilai, dan struktur), dan financial architecture. Hamel dan Prahalad menyebut strategic architecture sebagai high level blurprint for the deployment of new functionalities, the acquisition of new competencies, or the migration the reconfiguring of the interface with customers. Filosofi yang paling menarik dari strategic intent adalah the best way to predict the future is to create the future.

\section{Melihat Pandangan Baru Tentang Strategi}

Dasar pemikiran Prahald sederhana saja, persaingan meraih masa depan adalah persaingan untuk menciptakan dan mendominasi peluang yang muncul, memperebutkan ruang bersaing yang baru. Menciptakan masa depan lebih menantang dibandingkan mengejar ketertinggalan karena kita harus membuat sendiri peta jalan kita. Tujuannya bukan sekedar meniru produk dan proses pesaing serta meniru metodenya, melainkan mengembangkan titik pandang yang independen tentang peluang masa depan dan bagaimana memanfaatkannya. Menciptkan jalur (path breaking) jauh lebih menguntungkan dibandingkan mematok duga (bench marking). Orang tidak mungkin tiba paling dulu di masa depan dengan membiarkan orang lain menjadi perintis.

Tersirat disini bahwa pandangan tentang strategi sangat berbeda dari pandangan yang dianut di banyak perusahaan. Hal itu adalah pandangan tentang strategi yang menyadari bahwa perusahaan harus melepaskan sebagian besar masa lalunya sebelum perusahaan dapat menemukan masa depan. Hal itu adalah pandangan yang menyadari bahwa tidaklah cukup dengan hanya mendapatkan posisi optimal di pasar yang sudah ada; Tantangannya adalah menembus kebut ketidakpastian dan mengembangkan wawasan ke depan. Hal itu adalah pandangan tentang strategi yang menyadari diperlukan lebih daripada sekedar rencana tahunan tetapi yang dibutuhkan 
adalah arsitektur strategik yang memberikan cetak biru untuk membangun kompetensi yang diperlukan untuk mendominasi pasar masa depan.

Dengan pandangan baru tersebut, tidak perlu memikirkan ketidakcocokan antara tujuan dan sumber daya tetapi lebih mementingkan penciptaan tujuan abadi (stretch goals) yang menantang para karyawan untuk mencapai apa yang nampaknya tidak mungkin. Strategi adalah upaya untuk mengatasi kendala sumber daya melakui kegiatan kreatif tanpa akhir untuk mendapatkan resource leverage yang lebih baik.

\section{Ilustrasi Kompetensi Inti: Wal Mart}

Raksasa eceran Wal Mart dari Amerika itu membuktikan janjinya kepada konsumen. Wal Mart sanggup menurunkan harga sampai tiga kali dalam sehari. Pesaingnya yang merasa terancam, menuduh Wal Mart melakukan dumping. Akan tetapi, Wal Mart membantah seraya menunjukkan bagaimana cara berusaha eceran yang efisien. Sukses Wal Mart dalam melakukan cut cost itu bermula di awal tahun 1970-an. Ketika itu, di Amerika, Wal Mart melakukan dua langkah inovasi. Pertama, memusatkan barang yang dipesan pada satu tempat yang sekaligus menjadi pusat distribusi. Jadi, tidak ada satu pun outlet yang menerima barang langsung dari pemasok. Dengan cara itu, banyak biaya untuk gudang dan truk yang berangkat dari pusat distribusi akan selalu penuh dengan pesanan dari beberapa outlet.

Kedua, tahun 1980-an, Wal Mart mulai menerapkan sistem komputer terpadu yang menghubungkan 1800 tokonya dengan pusat distribusi sekaligus dengan para pemasok besar. Dengan Electronic Data Interchange (EDI) itulah, order pesanan, pengiriman bukti transaksi dan kuintansi penagihan dari toko ke pusat distribusi, dan dari pusat distribusi ke pemasok, berlangsung dengan cepat. Gerak cepat serupa juga dapat terlihat dari 25 pusat distribusinya. Disana ada ban berjalan yang dipandu dengan sinar laser sehingga setiap barang yang masuk langsung tercatat di komputer. Begitu pula dengan barang yang siap dikirim ke toko, melalui proses yang sama cepatnya.

Wal Mart memiliki kompetensi inti di manajemen logistik sehingga dapat mendomominasi bisnis eceran. Outlet yang dimiliki Wal Mart hampir merambah ke seluruh negara bagian Amerika dan luar Amarika. Dengan kompetensi inti di manajemen logistik, Wal Mart dapat menghemat banyak biaya produknya dan menghemat banyak waktu sehingga dapat menjual dengan harga di bawah harga pesaing.

\section{Hypercompetition (Richard A D’Aveni)}

Pada tahun 1980, Michael Porter dalam bukunya Competitive Strategy memberikan suatu teknik untuk menganalisis struktur industri dan lingkungan persaingan serta menyarankan langkah yang dapat diambil perusahaan untuk mendapat keunggulan bersaing. Dengan keunggulan yang dimiliki, perusahaan dapat memenangkan persaingan. Banyak perusahaan telah menempuh cara yang disarankan Porter untuk mendapatkan keunggulan bersaing. Akan tetapi, karena semua perusahaan berusaha memperoleh keunggulan bersaing sehingga tingkat persaingan semakin ketat. Keungulan yang dimiliki ternyata tidak dapat bertahan lama. Persaingan untuk mengungguli antara para pemain dalam suatu industri telah mengubah situasi persaingan dalam industri, dari yang tadinya relatif statis menjadi lebih dinamis, sehingga menyebabkan keunggulan bersaing tidak dapat bertahan lama (sustainable) karena keunggulan lainnya yang diciptkan pesaing. 
Situasi persaingan yang ditandai dengan dinamika tinggi tersebut, disebut oleh seorang guru besar di Amos Tuck School of Business Adminsitration di Darmout, Amerika yang bernama Richard A D'Aveni sebagai hypercompetition. Dalam bukunya Hypercompetition: Managing the Dynamics of Strategic Maneuvering yang disusun bersama Robert Gunther, D'Aveni menggambarkan proses keruntuhan dari apa yang dinamakannya keunggulan bersaing tradisional serta munculnya keunggulan baru dan memperkenalkan teknik baru untuk digunakan dalam menganalisis dinamika persaingan dalam situasi hypercompetition.

Konsep strategik lama seperti strategic fit, sustainable competitive advantage, barriers to entry, long rang planning, dan SWOT analisis menurut D’Aveni akan berguguran bila dinamika persaingan yang dihadapi adalah hypercompetition.

\section{Cara Baru Melihat Keungulan Bersaing}

Melihat keunggulan bersaing dengan cara baru adalah dalam pandangan yang dinamis. Dalam pandangan tersebut, ada beberapa ketentuan yang berlaku.

1. Setiap keunggulan akan mengalami erosi.

Hal itu berarti bahwa keungglan bersaing tidak akan tetap bertahan sebagai suatainable competitive advantage. Cepat atau lambat, pesaing akan meniru atau bahkan mengatasi keunggulan yang sudah dimiliki terebut. Bila hal tersebut terjadi maka keunggulan itu tidak akan berarti apa-apa lagi.

2. Membuat keunggulan bertahan lama berarti bunuh diri.

Berusaha mempertahankan keunggualn bersaing yang dimiliki, menurut D’Qveni berarti memberi kesempatan kepada pesaing untuk emperkuat diari dan mendapatkan keunggulan baru.

3. Tujuannya ialah meruntuhkan, bukan membuat sustainable competitive advantage.

Dalam situasi hypercompetition, tujuan utama strategi adalah meruntuhkan status quo dan mengambil inisiatif dengan menciptkan sederetan temporary competitive advantage. Dengan cara tersebut, perusahaan akan selalu selangkah di depan dibandingkan dengan para pesaingnya, bergerak dari satu keunggulan ke keunggulan yang baru.

4. Mengambil inisiatif dengan langkah kecil.

Karena siklus persaingan semakin pendek, kebutuhan untuk mendapatkan keunggulan baru dengan cepat menjadi meningkat. Dengan demikian, tidak mungkin lagi memikirkan strategi untuk lima atau sepuluh tahun ke depan. Hal yang dibutuhkan adalah serentetan langkah pendek yang akan diambil berurutan.

\section{Cara Lama Melihat Keunggulan Bersaing}

Cara lama melihat keunggulan bersaing, menurut D’Aveni, adalah persaingan berada dalam situasi relatif statis. Keunggulan bersaing dalam situasi statis tersebut, diperoleh dari keberhasilan dalam empat arena kunci persaingan sebagai berikut.

1. Harga dan Kualitas (Price and Quality) 
Pandangan yang paling sederhana tentang keunggulan bersaing adalah perusahaan bersaing dengan harga atau dengan kualitas barang. Dengan harga rendah diharapkan penjualan meningkat dan biaya tetap dapat dialokasikan pada volume penjualan yang besar. Harga rendah tersbut hanya mungkin jika biaya produksi juga rendah dan hal tersbut dapat dilakukan menggunakan konsep Porter Overall Cost Leadership. Dengan harga yang tinggi diharapkan dapat diperoleh margin yang tinggi dengan kualitas yang tinggi. Hal tersebut dapat dilakukan dengan konsep Porter Product Differentiation. Dalam pandangan itu, keunggulan yang dimiliki, baik berupa harga maupun kualitas, dapat bertahan lama dengan upaya tertentu. Akan tetapi, dalam pandangan yang lebih dinamis, kunggulan yang diperoleh, baik dengan harga maupun kualitas, tidak akan bertahan lama. Pesaing akan muncul dengan produk yang berkualitas atau dengan harga yang lebih rendah.

\section{Waktu dan Pengetahuan (Time dan Know-How)}

Arena persaingan kedua adalah dengan memasuki pasar lebih dulu dari pesaing dan dengan penguasaan teknologi. Dalam pandangan yang statis, keunggulan itu juga dapat dipertahankan dalam jangka waktu cukup lama. Namun, dalam pandangan yang lebih dinamis tentang keunggulan bersaing, masing-masing pesaing akan berusaha terlebih dahulu dalam memasuki pasar dengan menguasai teknologi untuk inovasi produk.

\section{Daerah Kekuasaan (Strongholds)}

Arena persaingan ketiga untuk mendapatkan keunggulan bersaing dalam pandangan statis adalah dengan membatasi jumlah pesaing dalam daerah kekuasaan tertentu dengan menciptakan Barrier to Entry. Dengan jumlah pesaing yang sedikit, masing-masing akan menikmati laba besar dan situasi itu akan bertahan selama Barriers to Entry dapat dipertahankan. Dalam pandangan yang lebih dinamis tentang keunggulan bersaing, Barriers to Entry pada akhirnya akan runtuh karena pesaing yang ingin masuk akan melakukan segalah upaya untuk mengatasi rintangan tersebut.

\section{Dompet Tebal (Deep Pocket)}

Arena persaingan keempat adalah menggunakan sumber daya yang lebih besar. Dengan banyaknya sumber daya yang digunakan, perusahaan akan memiliki kapasitas bersaing lebih besar. Akan tetapi, dalam pandangan yang lebih dinamis, keunggulan tersebut akan hilang bila beberapa pesaing membentuk aliansi untuk menghadapi perusahaan yang memiliki sumber daya lebih besar.

Pandangan dinamis tentang keunggulan bersaing, menurut D’Aveni didasarkan pada tiga prinsip dasar berikut.

\section{Interaksi Strategis yang Dinamis}

Prinsip pertama, bahwa dalam strategi bersaing, semua aksi sebenarnya adalah interaksi. Setiap langkah strategis yang diambil perusahaan sebenarnya adalah counte rmove atau sebagai antisipasi terhadap langkah pesaing. Dalam setiap interaksi yang dinamis, suatu perusahaan yang mengambil langkah untuk mendapatkan keunggulan sementara akan segera dibalas oleh pesaing untuk menetralisasi persaingan atau mendapatkan keunggulan baru. Perusahaan pertama akan terpaksa mengambil tindakan balasan lagi dan situasi itu akan terus berlanjut sehingga situasi persaingan dalam industri tersebut akan menjadi lebih ketat 


\section{Strategi adalah Relatif}

Prinsip kedua yang mendasari pandangan baru tengang keunggulan bersaing adalah bahwa tidak ada strategi yang mutlak, semuanya relatif. Posisi persaingan suatu perusahaan serta ketahanan keunggulan yang dimilikinya selalu dilihat dalam hubungannya dengan pesaing. Posisi perusahaan A dikatakan kuat sebagai low cost producer, kalah semua pesaing berada pada posisi yang lebih lemah. Artinya, biaya mereka lebih tinggi daripada perusahaan A. Begitu pula dalam hal ketahanan keunggulan yang dimiliki suatu perusahaan, hal itu dilihat dari reaksi pesaing terhadap keunggulan tersebut.

\section{Kecendrungan dalam Empat Arena Persaingan}

Prinsip ketiga adalah posisi strategis suatu perusahan tidak hanya relatif terhadap para pesaing tetapi juga dilihat dalam konteks sejarah interaksi yang dilakukan oleh pesaing. Oleh sebab itu, pesaing harus memproyeksikan kecendrungan jangka panjang untuk memahami ke mana arah persaingan tersebut. Keempat arena persaingan yang diuraikan menyediakan suatu kerangka yang berguna untuk menelusuri interaksi strategis yang dinamis antara pesaing dalam jangka waktu yang panjang dan untuk memahami evolusi industri.

\section{Tangga Eskalasi dan Hypercompetition}

Penelitian yang dilakukan D'Aveni tentang perjalanan sejarah dalam masing-masing arena persaingan memperlihatkan adanya dua jenis eskalasi.

\section{Eskalasi dalam Arena}

Suatu gerakan strategis dalam satu arena persaingan, umpamanya menurunkan harga yang lebih rendah dan seterusnya sehingga persaingan tidak berhenti mengalami eskalasi.

\section{Eskalasi Lintas Arena}

Karena tidak ada lagi ruang gerak dalam arena persaingan yang sama, persaingan dapat meningkat melintasi garus batas arena. Karena tidak mungkin lagi meningkatkan mutu produk, misalnya, perusahaan memasuki arena lain sehingga eskalasi persaingan berjalan dalam bentuk lintas arena. Eskalasi lintas arena tersbut, tidak berjalan secara beraturan tetapi dapat meloncat dan berputar balik

\section{Aturan Baru dalam Hypercompetition: 7 S Baru}

Berdasarkan hasil pengamatannya atas perusahaan yang berhasil dalam hypercompetition, D’Aveni mengemukakan satu set rancangan baru yang disebutnya $7 \mathrm{~S}$ baru. Konsep tersebut dimaksudkan untuk menggantikan kerangka 7 S dari McKinsey yang dikatakannya tidak lagi berlaku dalam situasi hypercompetition. Menurut McKinsey, keunggulan bersaing diperoleh dengan menciptakan keserasian (fit) antara karakteristik kunci organisasi dan memusatkan karakteristik tersebut pada satu tujuan atau misi. Hal itu menuntut adanya keserasian antara strategi organisasi dan lingkungan serta keserasian antara ketujuh faktor inti internal organisasi, yaitu structure, strategy, system, style, skill, staff, dan superordinate goals, yang biasa disebut $7 \mathrm{~S}$. 
Keserasian tersebut, menurut D’Aveni mengandung pengertian permanen. Dalam situasi hypercompetition, hal tesebut sudah kuno dan mudah dipatahkan pesaing. Pesaing bahkan dapat memanfaatkan $7 \mathrm{~S}$ itu untuk melancarkan serangan terhadap perusahaan sendiri. Ketujuh S baru yang disarankan D’Aveni sebagai berikut.

1. Superior stakeholder satisfaction

2. Strategy soothsaying

3. Posititioning for speed

4. Posititioning for surprise

5. Shifting the rules of competition

6. Signalng strategic intent

7. Simultaneous and sequential strategic thrust

Dua S pertama yang diperkenalkan D’Aveni menentukan sumber keunggulan baru dan cara memperolehnya. Superior stakeholders satisfaction adalah kunci untuk memenangkan setiap interaksi strategis yang dinamis dengan pesaing. Proses mengembangkan keunggulan baru atau menumbangkan keunggulan pesaing dimulai dengan memahami bagaimana memuaskan pelanggan. Dengan mengenali cara memuaskan pelanggan, perusahaan dapat mengindentifikasi langkah selanjutnya untuk mengambil inisiatif. Akan tetapi, pelanggan bukan satu-satunya stakeholders yang harus dipuaskan. Karyawan juga harus dipuaskan supaya perusahaan dapat melaksanakan langkah strategis.

Strategi soothsaying adalah proses mencari pengetahuan baru untuk meramalkan atau bahkan menciptakan peluang baru yang akhirnya akan dimanfaatkan pesaing tetapi saat ini tidak seorangpun yang menggunakannya. Kedua $\mathrm{S}$ tersebut berbeda dari pemikiran konvensional tentang keunggulan karena menurut konsep itu, sumber keunggulan dalam kemampuan untuk memenangkan setiap interaksi strategis yang dinamis dengan pesaing. Hal itu dicapai dengan menemukan cara memuaskan pelanggan dengan cara baru dan lebih baik daripada cara lama. Untuk itu, diperlukan dua kompetensi berikut.

1. Karyawan yang termotivasi dan mempunyai wewenang pada semua tingkatan organisasi.

2. Pengetahuan tentang masa depan atau kemampuan untuk menciptakan masa depan.

Semuanya itu memungkinkan perusahaan hypercompetition untuk meruntuhkan pasar dengan menciptakan peluang baru dan membuat kuno cara lama melayani pelanggan. Agar ceat mendapatkan manfaat dari visi yang diidentifikasi dengan $\mathrm{S}$ pertama, perusahaan harus mengembangkan kemampuan untuk meruntuhkan menggunakan dua S berikutnya, yaitu speed dan surprise. Dengan kemampuan itu, perusahaan dapat bereaksi dengan cepat terhadap peluang yang ada pada lingkungan atau secara proaktif membuat gerakan untuk mengungguli pesaing pada setiap tahapan dari interaksi strategis yang dinamis antara perusahaan.

Karena keunggulan mengalami erosi dengan cepat, kemampuan untuk bertindak dengan cepat dan mengejutkan menjadi sangat penting untuk merebut insiatif. Kecepatan dan kejutan dibutuhkan untuk memanfaatkan peluang, bergerak cepat menyerang pesaing, atau membalas serang pesaing. Kecepatan juga merupakan kunci dari keunggulan bersaing karena dengan itu kemampuan perusahaan akan bertambah untuk melayani pelanggan dan memilik waktu yang tepat untuk memasuki pasar. Kejutan juga sangat penting untuk keberhasilan. Semakin lama pesaing dapat ditunda memasuki pasar dengan serangan yang mengejutkan, semakin banyak waktu bagi perusahaan untuk memperkuat posisi di pasar. 
Kedua S itu menyarankan bahwa keunggulan dalam setiap interaksi strategis yang dinamis terletak pada kemampuan organisasi yang memungkinkan perusahaan mengungguli pesaing dengan kejutan dan kecepatan. Karena perusahaan hanya mempu menciptakan keunggulan sementara dengan setiap langkah baru untuk memuaskan pelanggan, diperlukan serangan yang cepat dan tanpa peringatan sebagai salah satu cara untuk mempertahankan keunggulan sementara selama mungkin.

Ketiga S terakhir berkenaan dengan taktik yang digunakan dalam lingkungan hypercompetition. Shifting the rules of competition berhubungan dengan tindakan yang menentukan medan pertempuran baru. Dengan mengubah aturan permainan, perusahaan menciptakan peluang baru untuk memuaskan pelanggan, cara baru melakukan transformasi pada industri. Perubahan aturan permainan itu tidak selalu merupakan hasil dari inovasi teknologi. Signals--peringatan verbal dari strategic intent--merupakan pengantar yang penting bagi tindakan yang lebih hebat. Signal dapat menahan tindakan pesaing atau menciptakan ketidapastian yang mengikis kemauan mereka untuk bertahan terhadap serangan. Jadi, signal dapat digunakan untuk meruntuhkan status quo dan interaksi antarperusahaan dan dengan demikian menciptakan keunggulan.

Simultaneous and sequential strategic thrust adalah penggunaan serangkaian tindakan yang dirancang untuk membingungkan pesaing dan meruntuhkan status quo untuk menciptakan keunggulan baru atau mengikis keunggulan pesaing. Dengan serangkaian serangan yang serentak atau berurutan, diharapkan perusahaan akan mendapatkan keunggulan. Ketiga S itu menyarankan bahwa memenangkan interaksi strategis yang dinamis ada hubungannya dengan cara terjadi interaksi tradisional antara pesaing menggunakan signal, cara bersaing baru dengan mengubah aturan permainan, dan tindakan serentak dan berurutan yang memanipulasi tindakan pesaing.

\section{Bentuk Baru Keunggulan Bersaing}

Dari penjelasan tersebut dapat disimpulkan bahwa satu-satunya keunggulan bersaing yang dapat bertahan lama adalah yang didasarkan pada pengetahuan bahwa $7 \mathrm{~S}$ baru memberikan jalan bagaimana mengendalikan interaksi strategis yang dinamis dengan pesaing. Dalam hypercompetition, penekanan diletakkan pada penggunaan interaksi strategis yang dinamais untuk menetralisasi keunggulan yang dimiliki pesaing atau bahkan menciptakan keunggulan baru.

\section{Ilustrasi Hypercompetition: Microsoft Coorporation}

Ilustrasi yang paling menarik adalah strategi yang diterapkan Bill Gates melalui Microsoft-nya. Microsoft melalui produk software MS_DOS berhasil merajai industri software komputer. Hal tersebut terlihat pada era 1980-an, hampir semua PC di seluruh dunia menggunakan MS-DOS sebagai operating system-nya. Saat itu, tidak terbayangkan bahwa MS-DOS justru hancur karena produk baru yang diluncurkan oleh Microsoft sendiri, yaitu Microsoft Windows. Saat ini, hampir semua PC di seluruh dunia menggunakan Microsoft Windows sebagai operating system-nya menggantikan MS-DOS.

Dalam industri software komputer yang persaingan sangat tinggi dan perubahan yang terjadi sudah merupakan hitungan detik, bukan lagi menit atau bahkan jam, persaingan sangat dinamis sehingga penerapan sustainable competitive advantage akan menyebabkan perusahaan tertinggal dibandingkan dengan para pesaing. Microsoft tidak terpaku mempertahankan 
keunggulan bersaing yang dimilikinya pada produk MS-DOS. Sebelum pesaing menciptakan keunggulan baru untuk mengalahkan keunggulan MS-DOS, Microsoft menciptakan keunggulan baru yang lain melalui produk Microsoft Windows-nya.

\section{Crafting Strategy, Henry Mintzberg}

Bayangkan bagaimana sebuah perusahaan membuat perencanaan strategi. Sebuah grup atau komite khusus dibentuk untuk membuat perencanaan strategi tersebut. Grup itu terdiri atas menajer senior, analis, dan staf ahli yang bekerja secara sistematis dan analitis dalam menganalisis kelebihan dan kelemahan perusahaan dan mengamati peluang serta ancaman yang akan dihadapi perusahaan. Dari analisis tersebut, grup memformulasikan strategi yang tepat bagi perusahaan dengan mempertimbangkan kondisi internal dan kondisi eksternal perusahaan.

Sekarang bayangkan seorang pelukis membuat lukisannya. Dengan keterampilan dan bakat yang dimilikinya, dia mencoba menuangkan aspirasinya dalam sebuah lukisan sehingga dia dapat membuat lukisan yang benar-benar dapat mengekspresikan apa yang dimilikinya dan apa yang menjadi harapannya. Hal itu yang menjadi ide Mintzberg dalam upaya perusahaan memformulasikan perusahaannya. Mintzberg berpendapat dalam memformulasikan strategi akan lebih efektif jika proses formulasi strategi tidak hanya berjalan secara mekanis tetapi lebih dari itu. Bagaikan seorang pelukis, dia duduk di antara masa lalu perusahaan yang mencerminkan kemampuan perusahaan dan masa depan perusahaan yang mencerminkan kesempatan di masa depan yang dengan keterampilan dan bakatnya mencoba melukis masa depan perusahaan sehingga dapat ditentukan strategi yang tepat dan efektif bagi perusahaan. Strategi diformulasikan melalui proses kreatif yang dikerjakan oleh orang yang ahli dan memiliki keharmonisan antara keterampilan dan bakat. Hal itulah yang merupakan esensi dari crafting strategy.

Beberapa hal yang harus diperhatikan dalam crafting strategy sebagai berikut.

1. Strategi merupakan gambaran antara kapasitas perusahaan di masa lalu dan kemampuan perusahaan menangkap peluang yang muncul di masa depan serta menghadapi ancaman yang muncul dalam lingkungan bisnis.

2. Strategi dapat ditentukan bukan hanya disengaja melalui suatu proses yang mekanis dan sistematis tetapi sering muncul dari proses kreatif dengan pola yang terkadang tidak sistematis.

3. Strategi yang efektif dikembangkan melalui berbagai cara yang kadang-kadang tidak lazim tetapi justru efektif dalam menentukan strategi yang tepat bagi perusahaan.

4. Dengan kondisi lingkungan yang terus menerus mengalami perubahan, penerapan manajemen strategi yang konvensional menjadi tidak efektif. Reorientasi strategi terjadi sangat cepat sehingga muncul yang disebut quantum leap. Penekanannya adalah pada kemampuan perusahaan dalam mengembangkan strategi baru dan kemampuan organisasi dalam beradaptasi dengan munculnya orientasi bisnis yang baru.

5. Dalam mengelola strategi, seorang ahli strategi digambarkan sebagai perencana atau penentu visi perusahaan yang harus memiliki kemampuan berikut.

a. Mampu mengelola kestabilan sehingga dapat meminimalkan faktor ketidakpastian.

b. Mampu mendeteksi suatu tren yang tidak umum atau tidak biasa. Tantangan besar dalam crafting strategy adalah dalam mendeteksi munculnya tren yang tidak umum atau tidak biasa dan memasukkannya dalam memprediksi bisnis di masa depan.

c. Memiliki pengetahuan yang mendalam mengenai bisnis yang dihadapinya. Bukan hanya pengetahuan intelektual dan kemampuan analisis terhadap fakta dan angka tetapi 
keterampilan pribadi, bakat, dan pemahaman yang mendalam mengenai bisnis akan sangat menentukan keberhasilan seseorang dalam mengelola strategi.

d. Mampu mengelola pola yang ada. Kemampuan untuk mendeteksi pola yang ada akan membantu perusahaan dalam menentukan bentuknya. Dalam organisasi yang kompleks berarti mengembangkan suatu struktur yang fleksibel, mempekerjakan sumber daya manusia yang kreatif, mendefinisikan strategi dalam konteks yang luas, dan memperhatikan terhadap pola yang mungkin muncul

e. Kemampuan merekonsiliasi perubahan yang terjadi dengan kontinuitas.

\section{PENUTUP}

\section{Simpulan}

Globalisasi ekonomi membawa pengaruh yang sangat pesat. Dalam memasuki abad ke21, ekonomi dunia sedang menghadapi realitas baru. Struktur dunia mengalami pergeseran yang intensif sejak beberapa tahun yang lalu. Tren tersebut mempengeruhi perkembangan manajemen strategi dengan rincian sebagai berikut.

1. Pada tahun 1980-an, muncul teori keunggulan kompetitif dari Michael Porter dan perusahaan yang memiliki keunggulan kompetitiflah yang akan memenangkan persaingan. Fokusnya adalah bagaimana perusahaan berupaya memiliki keunggulan kompetitif dan mempertahankannya sehingga perusahaan memiliki keunggulan kompetitif yang sustainable.

2. Selanjutnya, Hamel dan Prahalad memperkenalkan konsep kompetensi inti yang diartikan sebagai kemampuan korporasi melansir secara berkesinambungan collective learning untuk memungkinkan korporasi mengkonsolidasikan teknologi dan keterampilan produksi pada seluruh operasi korporasi, untuk menjadi kompeten yang beragam dalam memperkuat tiap unit bisnis dalam melakukan adaptasi secara cepat sehingga dapat memanfaatkan perubahan peluang. Kompetensi inti tidak lain merupakan investasi aset tangible dan intangible. Hamel dan Prahalad memunculkan strategi baru dan peruahaan harus fit dengan masa depan, bukan masa sekarang, agar perusahaan sedini mungkin berada di garis depan dalam keunggulan bersaing. Instrumen utama untuk bersaing di masa depan adalah pengembangan kompetensi inti yang menjadi dasar bagi penciptaan produk.

3. Industri menjadi semakin mengglobal sehingga bersifat dinamis dan move strategy pemain global menjadi semakin intensif sehingga kondisi pasar makin ditandari hypercompetition. Tiap keunggulan kompetitif menjadi bersifat sementara sehingga perusahaan dipaksa untuk meningkatkan kemampuan yang tidak bersifat fit dengan eksternal tetapi mentransformasikan terus menerus seluruh aspek manajemen internal agar selalu relevan dengan kondisi persaingan baru.

4. Terakhir, Henry Mintzberg memperkenalkan konsep crafting strategy yang menekankan pada formulasi strategi bukan hanya suatu proses yang mekanik dan sistematis. Akan tetapi, lebih dari itu merupakan suatu proses kreatif, yaitu keterampilan dan bakat angat membantu dalam menentukan keberhasilan perusahaan dalam memformulasikan strategi yang tepat dan efektif. 


\section{DAFTAR PUSTAKA}

D’Aveni, A and Robert Gunter. 1994. Hypercompetition: Managing Dynamic of Strategic Maneuvering. New York: The Free.

Hax, Arnoldo C. and Richard S.Majluf. 1984. Strategic Management: an Integrative Perspective. Englewood Clif: Prentice Hall.

Huseini, Martani. 1995. "Penciptaan Kompetensi Inti (Core Competence) sebagai Model Persaingan Bisnis Masa Kini.” Usahawan. No. 09 Th XXIV Sepetember 1995.

Prahalad, C.K. and Gary Hamel. 1990. The Core Competence of The Coorporation. Harvard Business Review. May-June.

Purnomo, Setiawan Hari Dan Zoelkiflimansyah. 1996. Manajemen Strategi: Sebuah Konsep Pengantar. Jakarta: Lembaga Penerbit FEUI. 